\title{
Design and Implementation of Personnel Tracking and Combat Vehicle Based on Microcontrollers
}

\author{
Yudi Efendi a,1,*, Petrus Gunawan, ${ }^{a, 2}$, Eko Kuncoro a,3 \\ ${ }^{\text {a }}$ Politeknik Angkatan Darat, Malang, Indonesia \\ ${ }^{1}$ kommil2510@gmail.com*; ${ }^{2}$ kommil2510@gmail.com; ${ }^{3}$ kommil2510@gmail.com \\ * corresponding author
}

Keywords

GPS

Sensor

Compass

Sensor

Balance

\begin{abstract}
Training is a necessity to achieve a level of professionalism in carrying out the main tasks of the Indonesian National Army (TNI) to safeguard the Sovereign State of the Republic of Indonesia (NKRI). With the development of technology, the flow of information that is well ordered, fast and interconnected is very important in a command control function that is packaged into a battle management. This study aims to create a system that can provide information support to the Unit Commander in giving command instructions to his troops. The information includes coordinates, altitude, balance, speed and compass, and is integrated with LCO (Lambert Conical Orthomophic) Map which can be integrated into Google Satellites so that tracking and monitoring of troops will be easier. Based on the results of tests that have been carried out it can be analyzed that the value of the error presentation of the actual measurements with measurements on the program is not too large. The comparison obtained is less than $2 \%$ so that by using the system it is expected that each unit can operate optimally and efficiently.
\end{abstract}

\section{Introduction}

The Indonesian National Army (TNI) is a state apparatus tasked with protecting the sovereignty of the Unitary Republic of Indonesia (NKRI). The increasing demands of the TNI's main tasks in maintaining the sovereignty of the Republic of Indonesia, especially the Indonesian Army (AD) training, is a need to achieve the desired level of professionalism and be well programmed and adapted to the times. The development of technology in carrying out training and operational tasks requires a facility that can be used as a monitoring tool for troops, with the aim to find out the position or location where troops are located[1]. However, the current troop monitoring system development is still ineffective because it still uses radio media[2]. One of the weaknesses of the radio is that it only conveys messages in the form of sound with half duplex communication. In this modern era the world of technology is developing very rapidly especially in the field of electronic communication there is technology that is able to provide information on the position of objects that are on the surface of the earth that is GPS technology (Global Position System)[3][4][5].

In general, GPS is used for tracking and navigation purposes in addition to that GPS is also used for transportation and military purposes. GPS history begins with the launch of satellites into Earth's orbit for the first time. The scientists found that they were able to track the movements of satellites by observing radio signal shifts. With GPS technology it will be easier to navigate digitally without having to open a map manually and calculate the coordinates of the position where personnel are located[6].

As a supporter of the exercise, the use of GPS technology can be used as a media for tracking and monitoring troops with system information including coordinates, altitude, balance, speed and compass, and applied with LCO (Lambert Conical Orthomophic) maps that have been integrated into Google Satellite so that the tracking and monitoring process will be easier[7]. With this system, it is expected to obtain optimal results and benefit the Army. 


\section{The Proposed Method}

In this research method, activities can be divided into two part, namely hardware design and software design. Hardware design includes making system block diagrams and component assembly. After the hardware design is complete then the software design continues, which can be integrated into the hardware device so that the data can be displayed in real-time.

\section{Method}

In general, the block diagram of a system design consists of a block diagram of a sender and a block diagram of a receiver. In the sender's block diagram section there are several modules namely Raspberry Pi-3 used to store and process the data received and then the data is sent to the recipient's monitor screen using the internet or facilities available on Raspberry Pi-3 [8][9], Ublox Neo-6M GPS is used to receive data on coordinates, altitude and speed, MPU6050 is used as a balance sensor, GY237 is used as a compass sensor, the camera is used to record an object, HT / Smartphone is used for communication in the form of voice. and the battery is used as a voltage source. Then the receiver block section consists of Monitor Screen / Laptop, RoIP (Radio over Internet Protocol), and HT/ Smartphone. The following is a block diagram of the system in this study shown in Figure 1:

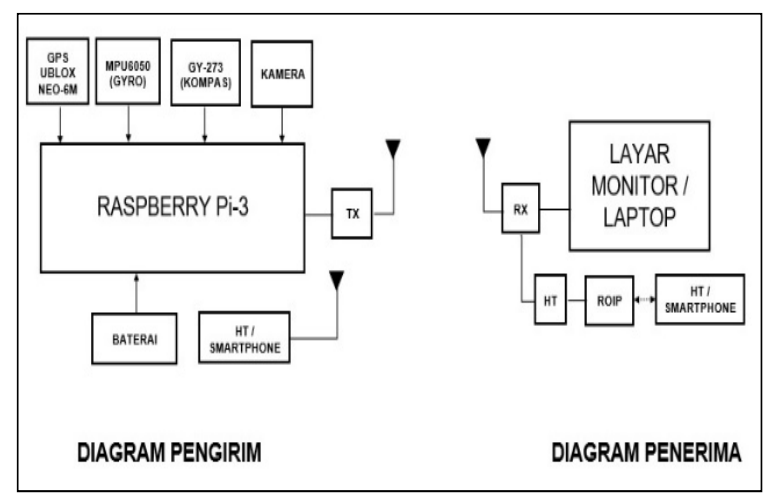

Fig. 1. Block Diagram

\subsection{Software Design}

Software design in this study is used to display data received from the block diagram of the sender. Software design includes login form and home form. The login form consists of the user name and password while the home form consists of video, device settings, maps, camera maps. The following is the software design shown in Figure 2

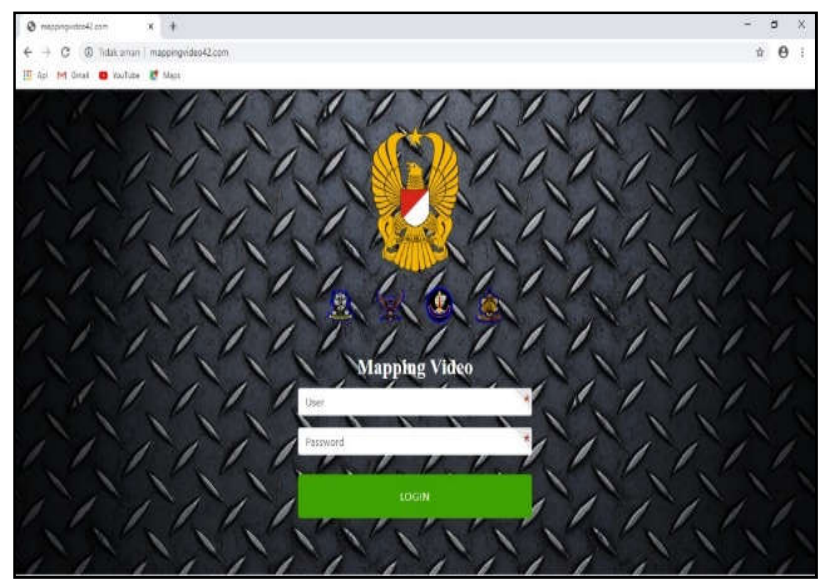

Fig. 2. Display Login 


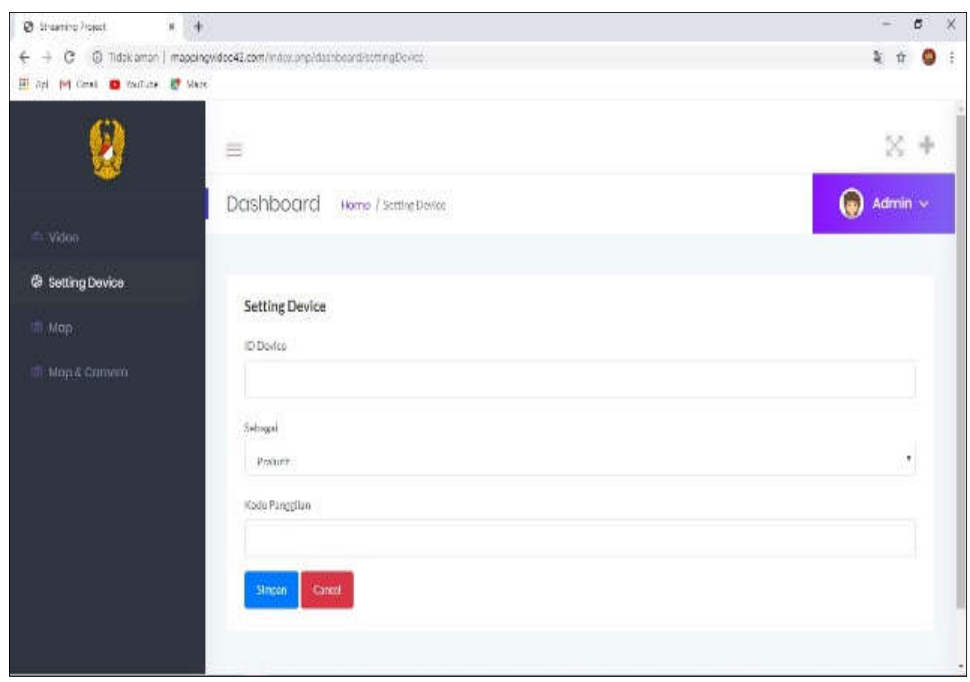

Fig. 3. Dispay Home

In this mapping display, there is an LCO map on Google Earth which is the target of the training used by the Army shown in Figure 4 as follows:

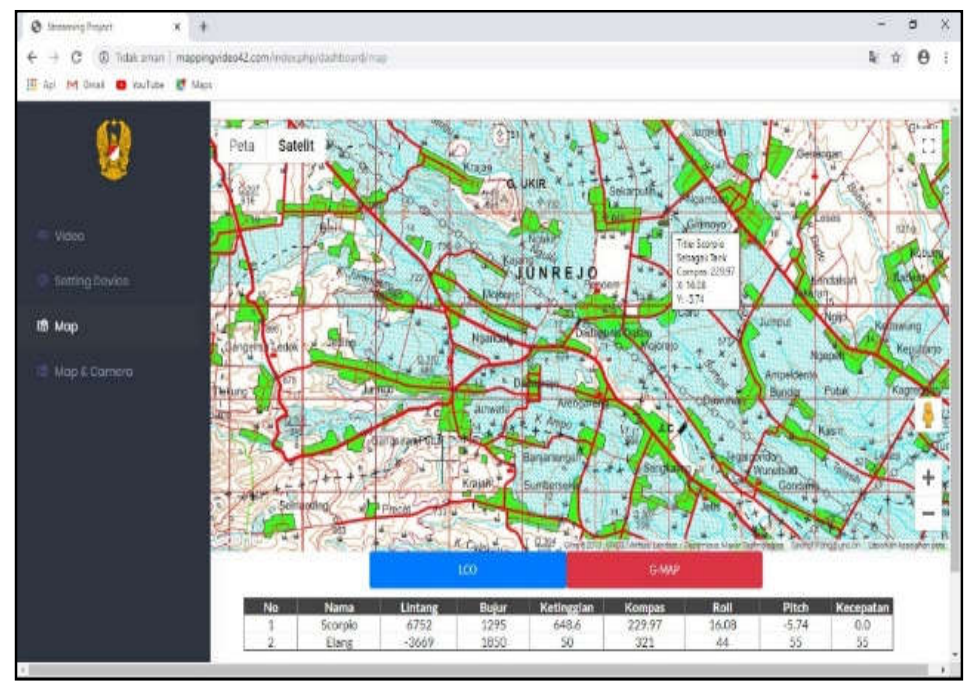

Fig. 4. Display Map

The appearance of the Map and Video is shown in Figure 5 as follows:

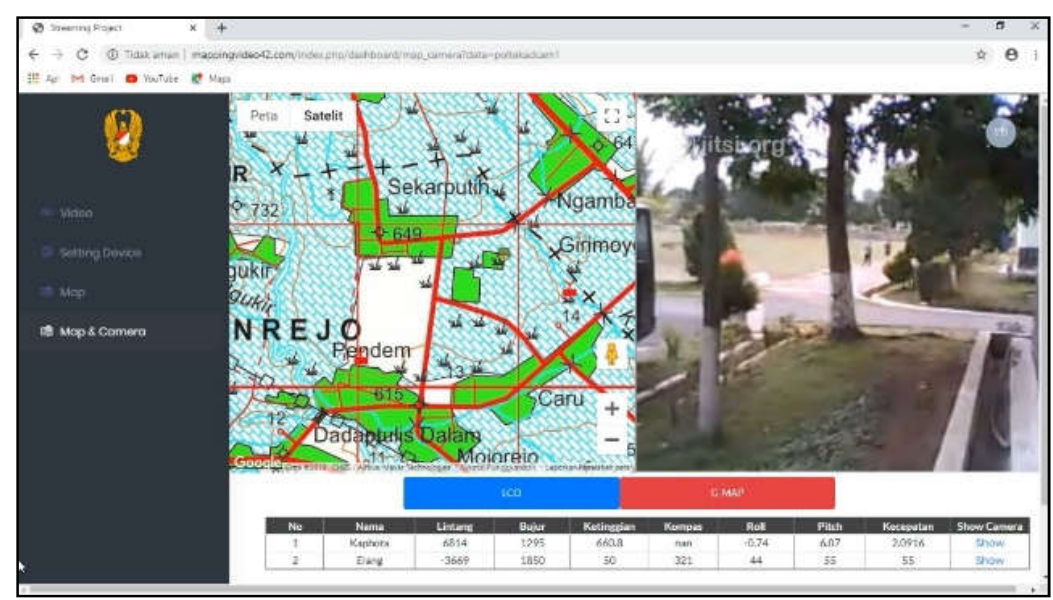

Fig. 5. Display Map and Video 


\section{Results and Discussion}

\subsection{GPS Testing}

Coordinate data obtained from the GPS module after being converted to LCO map coordinates that the coordinate data received by GPS is $-7.89457,112.58494$, there is a value of 6814,1295 which is the coordinate value of Malang LCO Map with 54 / XLII-A strands on a scale of 1: 50,000. The scale is an intermediate scale on the topographic map used by the army as a tactical map[10]. The conversion value from the test is shown in Table 1 .

Table 1. GPS Coordinate Test Results

\begin{tabular}{ccc}
\hline No. & $\begin{array}{c}\text { Geographical } \\
\text { Coordinates }\end{array}$ & LCO Coordinates \\
\hline 1 & $-7.91274,112.55059$ & 8787,9250 \\
\hline 2 & $-7.89827,112.53476$ & 7153,7400 \\
\hline 3 & $-7.89457,112.58494$ & 6814,1295 \\
\hline 4 & $-7.88897,112.56469$ & 6166,9996 \\
\hline 5 & $-7.88740,112.53067$ & 6012,6234 \\
\hline 6 & $-7.87863,112.52063$ & 5025,5550 \\
\hline 7 & $-7.86966,112.52789$ & 4008,5926 \\
\hline 8 & $-7.86449,112.50219$ & 3453,3700 \\
\hline 9 & $-7.85971,112.48782$ & 2898,1850 \\
\hline 10 & $-7.85639,112.48589$ & 2528,1850 \\
\hline
\end{tabular}

Based on Table 1. it can be analyzed that the value of GPS coordinates and LCO coordinates have changed, the more east the GPS testing at the equator, the coordinates will decrease.

\subsection{Altitude Testing}

Tests carried out are to determine the height of a particular place using GPS modules that have been installed on the hardware and compare with the height data obtained from the altimeter. This height data collection, carried out in several places that have different heights from low places to higher places. Comparative data are shown in Table 2. As follows:

Table 2.

Altitude Results

\begin{tabular}{cccc}
\hline No. & Altitude Altimeter (mdpl) & GPS Heigth $(\mathbf{m d p l})$ & Error (\%) \\
\hline 1 & 730 & 725.4 & 0.71 \\
\hline 2 & 886 & 879.7 & 2.71 \\
\hline 3 & 967 & 945 & 2.27 \\
\hline 4 & 963 & 950.6 & 1.28 \\
\hline 5 & 1116 & 998.3 & 1.74 \\
\hline
\end{tabular}

Based on Table 2. it can be analyzed that the percentage of errors less than $2 \%$ are data 1,4 and 5 . For data 2 and 3 have a greater percentage of errors because data 2 and 3 are closed rooms (indoor) so GPS is not able to work optimally because of the lack of satellite signals obtained.

\subsection{Speed Testing}

The speed test was carried out six times by measuring the speed from $10-60 \mathrm{~km}$. The testing phase compares the speed received by the GPS module with the speedometer on the car. Speed data obtained from the GPS module and speedometer are shown in Table 3. as follows:

Table 3. $\quad$ Speed Test Results

\begin{tabular}{cccc}
\hline No. & Speedometer $(\mathbf{k m})$ & Speed GPS $(\mathbf{k m})$ & Error $\mathbf{( \% )}$ \\
\hline 1 & 10 & 10.26 & 0.26 \\
\hline 2 & 20 & 20.12 & 0.12 \\
\hline 3 & 30 & 30.36 & 0.36 \\
\hline 4 & 40 & 40.06 & 0.06 \\
\hline 5 & 50 & 50.60 & 0.60 \\
\hline
\end{tabular}


Based on Table 3. it can be analyzed that the percentage error value from the actual measurement results with measurements in the program is not too large. The comparison is less than $2 \%$ so that the results of the testing program are close to the reading on the speedometer.

\subsection{Balance Testing}

This test aims to determine whether the MPU6050 sensor can function properly on the Raspberry Pi which will later be used to determine the position about the state of personnel or combat vehicles when used on real terrain. The following are the results of the tests shown in Table 4. As follows:

Table 4.

Speed Test Results

\begin{tabular}{cccc}
\hline No. & Protractor Dial & MPU6050 & Error (\%) \\
\hline 1 & $80^{\circ}$ & $80.43^{\circ}$ & 0.43 \\
\hline 2 & $70^{\circ}$ & $70.01^{\circ}$ & 0.01 \\
\hline 3 & $60^{\circ}$ & $60.54^{\circ}$ & 0.53 \\
\hline 4 & $50^{\circ}$ & $50.01^{\circ}$ & 0.01 \\
\hline 5 & $40^{\circ}$ & $40.14^{\circ}$ & 0.14 \\
\hline 6 & $30^{\circ}$ & $30.03^{\circ}$ & 0.03 \\
\hline 7 & $20^{\circ}$ & $20.09^{\circ}$ & 0.09 \\
\hline 8 & $10^{\circ}$ & $10.63^{\circ}$ & 0.63 \\
\hline 9 & $-10^{\circ}$ & $-10.16^{\circ}$ & 0.16 \\
\hline 10 & $-20^{\circ}$ & $-20.02^{\circ}$ & 0.02 \\
\hline 11 & $-30^{\circ}$ & $-30.24^{\circ}$ & 0.24 \\
\hline 12 & $-40^{\circ}$ & $-40.60^{\circ}$ & 0.60 \\
\hline 13 & $-50^{\circ}$ & $-50.49^{\circ}$ & 0.49 \\
\hline 14 & $-60^{\circ}$ & $-60.01^{\circ}$ & 0.01 \\
\hline 15 & $-70^{\circ}$ & $-70.36^{\circ}$ & 0.36 \\
\hline 16 & $-80^{\circ}$ & $80.22^{\circ}$ & 0.22 \\
\hline
\end{tabular}

Based on Table 5. it can be analyzed that the percentage of errors obtained is less than $2 \%$ so that the results of the testing program are close to the actual measurements. E. Compass Testing This test aims to determine whether the sensor GY-273 (compass) can function properly. In the compass reading the North direction is stated with a value of $0^{\circ}$ or $360^{\circ}$, East direction $90^{\circ}$, South direction $180^{\circ}$, and West direction 270 Following are the results of the compass test shown in Table 6 . As follows:

Table 5. Compass Test Results (GY-273)

\begin{tabular}{ccccc}
\hline No. & Wind direction & The degree of the Wind Eye & GY-273 & Error (\%) \\
\hline 1 & Utara & $0^{\circ} / 360^{\circ}$ & 359.89 & 0.03 \\
\hline 2 & Timur & $90^{\circ}$ & 90.64 & 0.64 \\
\hline 3 & Selatan & $180^{\circ}$ & 180.32 & 0.32 \\
\hline 4 & Barat & $270^{\circ}$ & 270.42 & 0.42 \\
\hline
\end{tabular}

Based on Table 6. can be analyzed that the error value from reading GY-273 (compass) is not too large. The comparison obtained is less than $2 \%$ so that the results of the testing program are close to the same as the reading in the actual cardinal direction.

\section{Conclusion}

In the results of the speed, balance and compass test results obtained the value of the percentage error is less than $2 \%$ so that the results of the program testing approach the same as the reading on the actual measurement, but on the results of the height test results obtained the value of the percentage error of more than $2 \%$ is data 2 and 3 because GPS is in a closed room (indoor) so that the GPS is not able to work optimally because of the lack of satellite signals that it gets. 


\section{References}

[1] M. Ismail, J. P. Hapsari, and S. A. D. Prasetyowati, "Aplikasi Mobile Untuk Pencegahan Pencurian Kendaraan Menggunakan Protokol IEEE 802.11," Setrum Sist. Kendali-Tenaga-elektronikatelekomunikasi-komputer, vol. 7, no. 1, pp. 117-126, 2018.

[2] R. Arifuddin, D. R. Santoso, and O. Setyawati, "Pengembangan Sistem Akuisisi Data Nirkabel untuk Pengukuran Distribusi Suhu Bawah Permukaan,” J. EECCIS, vol. 9, no. 2, pp. 123-129, 2016.

[3] N. K. Staal, S. R. Sentinuwo, and A. M. Sambul, "Rancang Bangun Aplikasi Pemantauan Trafik Lalu Lintas Menggunakan GPS Smartphone,” J. Tek. Inform., vol. 13, no. 1, 2018.

[4] B. Bahar and A. Hanafi, "Sistem Keamanan Kendaraan Bermotor Menggunakan GPS Berbasis SMS Gateway,” Jutisi J. Ilm. Tek. Inform. dan Sist. Inf., vol. 6, no. 3, pp. 1647-1654, 2018.

[5] M. A. Indrajaya, A. Affandi, and I. Pratomo, "PERANCANGAN AUTOMATIC VEHICLE LOCATION TRACKING SYSTEM BERBASIS WEB MAPPING MENGGUNAKAN GPS DAN GIS PADA KENDARAAN ANGKUTAN UMUM," in Prosiding SENTRA (Seminar Teknologi dan Rekayasa), 2018, no. 1 .

[6] B. Beny, J. Budiman, and A. Nugroho, "Implementasi Geofencing Pada Aplikasi Layanan Pemantau Anak Berbasis Lokasi," in Prosiding 2nd Seminar Nasional IPTEK Terapan (SENIT) 2017, 2017, vol. 2, no. 1, pp. 63-66.

[7] D. Supriyanti, R. Sari, and N. G. Amir, "Google Map Untuk Kepentingan Transportasi Berbasis Aplikasi,” J. Sensi, vol. 4, no. 1, pp. 64-76, 2018.

[8] A. Sedayu, E. Yuniarti, and E. Sanjaya, "Rancang Bangun Home Automation Berbasis Raspberry Pi 3 Model B dengan Interface Aprlikasi Media Sosial Telegram sebagai Kendali," Al-Fiziya J. Mater. Sci. Geophys. Instrum. Theor. Phys., vol. 1, no. 2, pp. 42-47, 2018.

[9] P. D. P. Adi and R. Arifuddin, "Design Of Tsunami Detector Based Sort Message Service Using Arduino and SIM900A to GSM/GPRS Module," JEEMECS (Journal Electr. Eng. Mechatron. Comput. Sci., vol. 1, no. 1, pp. 1-4, 2018.

[10] A. A. Utama, A. Rabi, and Y. Novianto, “Aplikasi Pengkonversi Koordinat Universal Transverse Mercator (UTM) dalam Operasi Tempur Menggunakan Metode Regresi Linier,” Ina. Indones. J. Electr. Eletronics Eng., vol. 1, no. 2, pp. 19-24, 2018. 